\title{
Article \\ Spectral Map-Based Tool for Backhaul Rural Network Optimization and Indirect Estimation of Demographic Behaviors
}

\author{
Claudia Lucía Cortés ${ }^{1, *,+}\left(\mathbb{D}\right.$, Mauricio Alejandro Montaño-Argote ${ }^{2,+} \mathbb{C}^{-}$and Neil Guerrero-González ${ }^{1,+}+(\mathbb{C}$ \\ 1 Facultad de Ingeniería y Arquitectura, Universidad Nacional de Colombia, Manizales 170003, Colombia; \\ nguerrerog@unal.edu.co \\ 2 Facultad de Ciencias Jurídicas y Sociales, Universidad de Caldas, Manizales 170003, Colombia; \\ m.montanho.a@gmail.com \\ * Correspondence: clcortesc@unal.edu.co \\ + These authors contributed equally to this work.
}

check for

updates

Citation: Cortés, C.L.; Montaño-

Argote, M.A.; Guerrero-González, N. Spectral Map-Based Tool for Backhaul Rural Network

Optimization and Indirect Estimation of Demographic Behaviors. Appl. Sci. 2022, 12, 2508. https://doi.org/ 10.3390/app12052508

Academic Editors: Jose Machado and Subhas Mukhopadhyay

Received: 9 November 2021

Accepted: 7 February 2022

Published: 28 February 2022

Publisher's Note: MDPI stays neutral with regard to jurisdictional claims in published maps and institutional affiliations.

Copyright: (C) 2022 by the authors. Licensee MDPI, Basel, Switzerland. This article is an open access article distributed under the terms and conditions of the Creative Commons Attribution (CC BY) license (https:// creativecommons.org/licenses/by/ $4.0 /)$.

\begin{abstract}
In this article, both the optimization of a backhaul network and the indirect estimation of demographic behaviors from spectral analysis are proposed. Electromagnetic spectrum in $5 \mathrm{GHz}$ frequency band was scanned, and graphs generation associated with the spectral map were obtained using AirView Spectrum Analyzer software incorporated into Ubiquiti devices; these devices were installed in Ovejas and Chalán municipalities as part of a rural backhaul network located in Sucre, Colombia to bridge the digital divide in rural areas. In addition to telecommunications system working frequency optimization between Almagra and La Ceiba nodes, which was configured at $5790 \mathrm{MHz}$ - spectral analysis is presented as a non-traditional information source of demographic behavior, an indirect measure of population data from rural and difficult access areas. Initially, power intensity levels measured in Almagra and La Ceiba nodes based on the spectral map are presented as a tool to continuously measure the demographic behavior relating telecommunications equipment use to population density.
\end{abstract}

Keywords: backhaul networks; rural connectivity; urban rural gaps; spectral analysis; population density

\section{Introduction}

Use and access of information and communication technologies (ITCs) are identified worldwide as fundamental factors for the economic and social development of each country, especially for underdeveloped or emerging countries where inequalities are present in everyday life. For this reason, in 2015, the United Nations (UN), through the Sustainable Development Goals (SDG), presented the objectives that would govern the countries strategic development until the year 2030. SDG goal nine (9), entitled "Build resilient infrastructure, promote inclusive and sustainable industrialization and foster innovation", in its target 9.C states, "Significantly increase access to information and communication technology and strive to provide universal and affordable access to the Internet in least developed countries by 2020" [1].

International Telecommunications Union (ITU) statistics on the behavior of global ICT development indicators from 2001 until 2019 show the progress in subscribers per 100 inhabitants for mobile telephony, Internet use, fixed telephony, mobile broadband, and fixed broadband [2]. Except for fixed telephony subscriptions, the indicators have increased since the "Millennium Declaration" in 2000 (see Figure 1) when the objectives prior to the SDGs were presented. Despite the efforts made by different governments, there are notable deficiencies in terms of fixed broadband connections and individuals who use the Internet worldwide. 


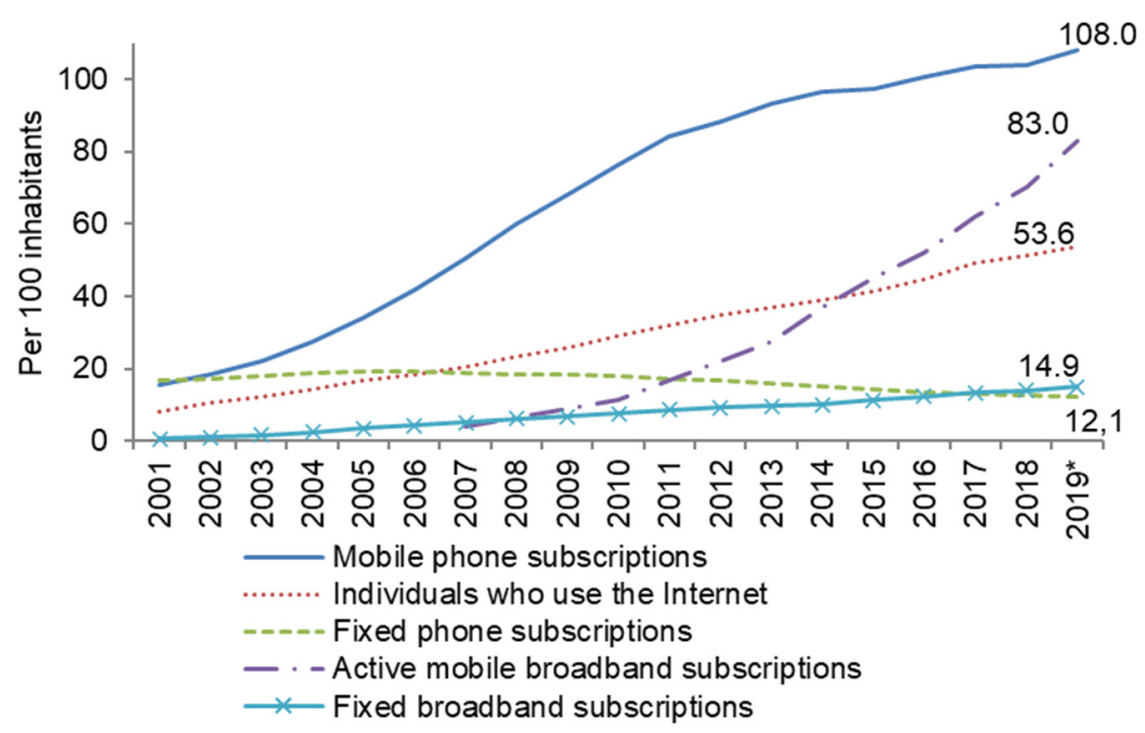

Figure 1. Global ICT development indicators, 2001-2019* (* estimated). Source: ITU World Telecommunication/ICT Indicators database [2].

Against this backdrop, different technological institutions, companies, and organizations have advanced regarding the development of technologies that can facilitate ICT access economically sustainable initiatives that allow connecting rural areas where around $60 \%$ of the population without connectivity resides [3]. Such is the case of Google Loon balloons, Facebook Aquila drone, low-orbit satellites, Fraunhofer Fit Institute technology WiBACK, or efforts to implement free cellular network technologies allowing broader coverage of mobile operators to rural areas at a more accelerated rhythm.

Reduce the digital divide, understood as "the separation that exists between people (communities, states, countries ... ) that use information and communication technologies (ICT) as a routine part of their daily life and those that do not have access to same and that, even if they have them do not know how to use them" [4]; as part of the social and economic revolution necessary to promote the most vulnerable population development and thus, provide opportunities regarding education, economics, research, and health services. For example, in Montes de Maria subregion, Colombia, there is a Plan of Action for Regional Transformation (PATR—Plan de Acción para la Transformación Regional) which raises as objective to improve the transport, energy, connectivity, irrigation, and drainage infrastructures for agricultural production that allows regional integration and access to goods [5].

Some difficulties that must be overcome from government institutions to carry out social intervention projects are associated with both up-to-date information on territorial realities such as demographic density, territorial location, and installed capabilities, as well as the precariousness of transport infrastructure, decisively to improve accessibility and increase productivity, or network infrastructure to improve digital connectivity.

The absence of updated information and the lack of adequate infrastructure make it difficult to access public information as an essential condition for government institutions' trust generation, while distrusting the institutionality makes it difficult for social interaction and becomes an obstacle to sustainable and human development [6].

This work is part of Colombia Científica Program entitled "Reconstrucción del Tejido Social en Zonas de Posconflicto", and one of its objectives is to integrate connectivity services to rural development models through the backhaul network design and installation to improve rural connectivity areas of Sucre department, Colombia. WiBACK is the backhauling strategy implemented, which was presented in 2016 by the Fraunhofer Institute of Applied Information Technology and has the advantage of being designed with software-defined network features (SDN) [7]. In addition, it has advantages associated with the rapid and expandable infrastructure installation and simultaneously allows both an 
indirect measurement of territory demographic characteristics, as well as the optimization of telecommunications system bandwidth from the spectral map measurement.

The spectral map is a graphic representation of signals generated by wireless telecommunications equipment in a given area, which allows its transmission frequencies identification. In-use frequencies and free frequencies analysis is a tool widely used for wireless networks design and optimization in telecommunications. Spectral analysis, especially in rural areas where the population is dispersed in a broad and difficult access territory for government entities, can serve as a tool to obtain information about the demographic behavior relating telecommunications equipment use to population density.

This document presents the spectral analysis of a backhaul rural network located in Sucre, Colombia, to extend connectivity from the core network located in the city of Chalán to rural communities of Ovejas and Chalán municipalities. First, Colombian and local contexts are presented. Then, the connectivity network and network configuration are described. Later, spectral measurements to compare the electromagnetic spectrum occupation between an area with a scattered population and an area with a higher population density are performed. Finally, the conclusions section is presented. Spectral map analysis allows both, directly, the working frequency optimization between Almagra and La Ceiba nodes, which was configured at $5790 \mathrm{MHz}$, and indirectly, spectral map analysis is presented as a tool to measure the demographic behavior relating telecommunications equipment use to population density.

This document focuses on electromagnetic spectrum analysis of the project objective territory, understanding the scarce of this resource and the importance of its management for maximum use in territory planning development actions and to reduce the digital divide in Colombia.

\section{Connectivity in Colombia}

Colombian National Planning Department (DNP-Departamento Nacional de Planeación), together with Information Technologies and Communications Ministry (MinTIC-Ministerio de las Tecnologías de la Información y las Comunicaciones), proposes the projected goals for the fulfillment of ODS 9-goal 9.C [8].

Since 2010 MinTIC has carried out its project "Plan Vive Digital para la Gente", divided into four components: Users, Infrastructure, Services, and Applications; each one is focused on developing initiatives to build a digital environment.

The Users component seeks to promote digital culture and use and appropriation of ICT by citizens through ICT certifications, skills training courses, and the Redvolución program [9]. The Infrastructure component, one of the most important, proposes initiatives for network infrastructure expansion with the "National Fiber Optic Project", which aims to connect 788 municipalities to improve the coverage of services nationwide; Another project is the "National High Speed Connectivity Project" which aims to provide 100\% coverage to municipalities in the country. Other projects are: "Digital Connections" which seeks to provide broadband services to households in strata 1 and 2; "Kioscos Vive Digital" for providing ICTs public access to rural communities; "Puntos Vive Digital" to train citizens in digital skills in different urban centers; and the project of "Free Wi-Fi Zones for People" that provides free Internet connection in public spaces with greater attendance in municipalities across the country. On the other hand, regarding access to public television, there are initiatives to provide universal access to this service using Digital Terrestrial Television (DTT) technology.

The Services component defines the quality of broadband connections and initiatives to strengthen both the information technology industry and the MSMEs (Micro, small and medium-sized enterprises); additionally, "Computadores para Educar" initiative seeks to improve the quality of education through technological tools. On the other hand, the Applications component seeks to promote the applications and content industry. For example, through the "Apps.co" initiative, entrepreneurship is promoted and strengthened by creating business environments and skills development; also, the creation of digital content for 
creative industries is also encouraged. Finally, through "ICT and Agro" initiative strategies that help to improve environmental processes generating economic and production are developed [10].

In addition to the "Plan Vive Digital para la Gente" project, in 2016, MinTIC, in alliance with Microsoft company, carried out three pilot tests with TV White Space (TVWS) technology. Three schools located in rural areas were connected to broadband Internet in the municipalities of Dibulla, Guajira; Pamplonita, Norte de Santander; and Aguadas, Caldas. As a result, it was possible to bring the Internet to more than 200 students, which prompted the need to regulate the television white spaces use [11].

On the other hand, private companies have shown their efforts to reduce the digital divide in Colombia. For example, Blazing Soft, in partnership with German FraunhoferGesellschaft Institute, implemented WiBACK technology in the municipality of La Jagua de Ibirico, Cesar. In conjunction with the "Nativos Digitales" project, they managed to bring broadband Internet connection to four rural schools, thus promoting technological appropriation and pedagogical skills development. The same partnership also, in cooperation with the Sugar Cane Research Center in Colombia (Cenicaña), started a pilot test of this technology in the Automated Meteorological Network where Internet access was difficult through conventional telecommunications infrastructure [12].

Colombian government initiatives to bridge the digital divide in rural areas have concentrated efforts on offering broadband connectivity through conventional telecommunications infrastructure with high maintenance costs using technology not specifically designed for rural topology. WiBACK technology is a wireless backhaul solution that connects rural areas and municipalities to the Internet. WiBACK extends existing networks such as an extension cable over long distances and connects hard-to-reach areas to the network [12].

These public and private initiatives have encouraged the building of a better country and have been a key factor for the digital divide closing. However, the needs and respective solutions regarding last-mile devices and power supplies must be considered.

\subsection{WiBACK Rural Backhaul Network: Technological Comparison}

WiBACK provides the technology to connect rural areas with limited or no Internet connection to remote network infrastructure while at the same time being able to cope with geographical disparities as well as the exposure to harsh environmental conditions [12] In Table 1, the main characteristics of WiBACK nodes are compared with similar wireless backhaul technologies that use the $5 \mathrm{GHz}$ unlicensed frequency band to communicate. The selected technologies are Cambium Networks PTP 550 [13], Mimosa B5c [14], and Mikrotik RB921UAGS-5SHPacT-NM [15].

Table 1. WiBACK technological comparison.

\begin{tabular}{ccccc}
\hline Characteristic & $\begin{array}{c}\text { WiBACK Node-2- } \\
\text { Connect-II [16] }\end{array}$ & $\begin{array}{c}\text { Cambium Networks } \\
\text { PTP 550 [13] }\end{array}$ & Mimosa B5c [14] & $\begin{array}{c}\text { Mikrotik } \\
\text { RB921UAGS- } \\
\text { 5SHPacT-NM [15] }\end{array}$ \\
\hline Frequencies & $5180-5800 \mathrm{MHz}$ & $5170-5980 \mathrm{MHz}$ & $4900-6200 \mathrm{MHz}$ & $4920-6100 \mathrm{MHz}$ \\
Receive sensitivity & $-96 \mathrm{dBm}$ & $-92 \mathrm{dBm}$ & $-93 \mathrm{dBm}$ & $-96 \mathrm{dBm}$ \\
Transmit power (maximum) & $30 \mathrm{dBm}$ & $26 \mathrm{dBm}$ & $30 \mathrm{dBm}$ & $33 \mathrm{dBm}$ \\
Throughput & $400 \mathrm{Mbps}$ & $1.4 \mathrm{Gbps}$ & $1.5 \mathrm{Gbps}$ & $1.3 \mathrm{Gbps}$ \\
Power consumption (maximum) & $15 \mathrm{~W}$ & $30 \mathrm{~W}$ & $1 \mathrm{~W}$ & $25 \mathrm{~W}$ \\
Latency & $2 \mathrm{~ms}$ & $3 \mathrm{~ms}$ & 1 & Not specified \\
Capacity for independent link & 2 & 1 & 1 \\
\hline
\end{tabular}

Source: self-made.

Comparing the characteristic's values among technologies in Table 1 , similar values can be seen in Receive Sensitivity, Transmit Power, and Latency. However, in Throughput, Power consumption, and Capacity for independent link values, great advantages can 
be highlighted. Regarding Throughput, WiBACK technology is at least 30\% lower than the other technological options under comparison. Another significant advantage of WiBACK technology is related to Power Consumption and Capacity for independent link characteristics. According to WiBACK technical data sheet, each node has an average consumption of $9 \mathrm{~W}$ DC (maximum $15 \mathrm{~W}$ DC) for two point-to-point wireless links. Unlike the other technological options under comparison, WiBACK maximum power consumption is almost half the value, and Capacity for independent link is doubled. WiBACK capacity to establish two individual wireless links makes it ideal to function as a signal repeater node. It means that two independent nodes, one to receive and one to transmit, are not needed to be grouped on the same tower to retransmit the received wireless signal. This characteristic decreases the amount of equipment needed for network implementation depending on its topology.

Finally, WiBACK is a plug-and-play technology, easy to build and operate, which means that its installation time is lower than the other technological options under comparison. The most demanding part of setting up a network with WiBACK is the planning and the physical effort of mounting the WiBACK nodes [12].

\subsection{Territorial Dynamics in Ovejas and Chalán Municipalities, Sucre, Colombia}

Colombian Caribbean territory known as Montes de María is historically recognized for its organizational capacity. This is corroborated by Commerce Chamber data that registers in the subregion 261 organizations classified as associations, cooperatives, corporations, and foundations [17].

Ovejas and Chalán municipalities are part of the 15 municipalities that make up Montes de María subregion [18], territories, where in 2020, a backhaul telecommunications network was installed in the townships of La Peña, La Ceiba, the village of Almagra, and the municipal seat of Chalán. The objective of this network was to strengthen the organization's capacities from different actions, one of them the digital divide reduction [19]. In Ovejas and Chalán municipalities, the Internet connection is below department and country average. In 2019, broadband penetration in Ovejas and Chalan was $2.67 \%$ and $0.14 \%$, respectively, while in the Sucre department, broadband penetration was $5.94 \%$ and $48.8 \%$ for Colombia $[20,21]$.

On the other hand, demographic and population dynamics associated with postconflict and the peace agreements implementation processes cause permanent civilian population displacements, generally not premeditated, from and to townships within the Montes de María. This floating population modifies the coexistence and work relationships and, therefore, continuously transforms the social and economic dynamics of the communities, making it difficult to create and continue social programs oriented toward inclusion and territorial integration [22,23]. Thus, it is necessary to propose non-traditional or alternative sources of population data complementary to main sources (population census, surveys, and vital statistics) that ideally deliver reliable results in short periods of time and that allow instant and indirect measurement of population data from rural and hard-to-reach areas [24].

According to Unified Victims Registry (RUV—Registro Único de Víctimas) [25], in the 1990s and 2000s, these territories were greatly affected by the armed conflict, which left between $82 \%$ and $85 \%$ of the population as armed conflict victims. According to the National Administrative Department of Statistics (DANE-Departamento Administrativo Nacional de estadísticas) 2020 projections, Ovejas will have a population of 20,806 inhabitants (urban 12,067 and rural 8739). For its part, Chalán will have a population of 4431 inhabitants (2792 live in the municipal seat and 1639 in rural areas) [26].

Ovejas and Chalán territories are part of Colombian 170 municipalities where Development Plans with a Territorial Approach are implemented, whose conception promotes the closing of rural-urban gaps [27]. By 2028, Montes de María projects to be an innovative territory leader in agroecological production, with community tourism development and 
an educated, organized, and empowered population that fosters peasant participation and autonomy [5].

\section{Scenario Description and Connectivity Network Configuration}

A WiBACK backhaul network detailed design to expand connectivity in Ovejas and Chalán municipalities rural areas was presented in the work of [19]. Network design was carried out in three stages: (i) theoretical projection and field study, (ii) calculation of parameters prior to links simulation according to WiBACK technology requirements, and (iii) designed links simulation results. The network projected and installed in 2020 consists of three links as presented in Table 2 and four geographical points (see Table 3), which are communicated wirelessly through radio links in $5 \mathrm{GHz}$ unlicensed band using star topology as presented in Figure 2.

Table 2. Coordinates and reference symbols of populations located in Figure 2.

\begin{tabular}{ccccc}
\hline Population & Latitude & Longitude & Symbol & Elevation (m.a.s.1.) \\
\hline Almagra & $9.55^{\circ}$ & $-75.25^{\circ}$ & Rhombus & $375 \mathrm{~m}$ \\
Chalán & $9.54^{\circ}$ & $-75.31^{\circ}$ & Triangle & $295 \mathrm{~m}$ \\
La Ceiba & $9.57^{\circ}$ & $-75.30^{\circ}$ & Square & $303 \mathrm{~m}$ \\
La Peña & $9.52^{\circ}$ & $-75.18^{\circ}$ & Circle & $218 \mathrm{~m}$ \\
\hline
\end{tabular}

Source: self-made.

Table 3. Connectivity links origin and destination referenced in Figure 2.

\begin{tabular}{cccc}
\hline Link & Origin & Destination & Color \\
\hline 1 & Chalán & Almagra & Cyan \\
2 & Almagra & La Ceiba & Yellow \\
3 & Almagra & La Peña & Green \\
\hline
\end{tabular}

Source: self-made.

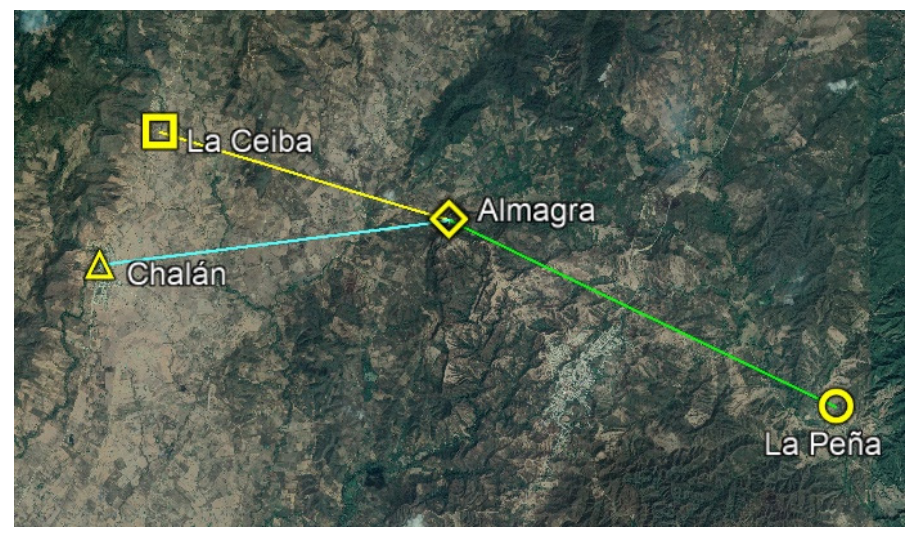

Figure 2. Wireless links and node's location. Source: generated in Google Earth Pro.

The primary node is located at Chalán urban area (triangle), which connects with the repeater node located on Almagra hill (rhombus), Ovejas rural area, from there, the signal is retransmitted to La Ceiba (square) and La Peña (circle) townships of Chalán and Ovejas, respectively [19]. Network optimization is carried out in three stages: (i) technology requirements fulfillment according to final field study and network design, (ii) link-level measurements, and (iii) spectral measurement results.

Due to financial issues, two types of technologies for radio link transmitters and antennas were installed. WiBACK was the main technology installed, links 1 and 3, and for link 2, airMax technology from Ubiquiti was chosen (see Table 3 and Figure 2). One of the great advantages of using WiBACK technology is its compatibility with any IP network device if the technical requirements necessary to establish point-to-point wireless links 
are met. Technical characteristics of both technologies (communication parameters and energy consumption) are shown in Table 4. Developed by Ubiquiti Networks Inc., airMax technology was designed for outdoor wireless links use with low latency and high transfer rate and point-to-point links or point-multipoint links through free use frequencies [28].

Table 4. WiBACK Node-2-Connect-II and Ubiquiti PowerBeam PBE-M5-400 technical characteristics.

\begin{tabular}{ccc}
\hline Characteristic & WiBACK & Ubiquiti \\
\hline Frequencies & $5180-5800 \mathrm{MHz}$ & $5150-5875 \mathrm{MHz}$ \\
Antenna gain & $23 \mathrm{dBi}$ & $25 \mathrm{dBi}$ \\
Receive sensitivity & $-96 \mathrm{dBm}$ & $-96 \mathrm{dBm}$ \\
Transmit power (maximum) & $30 \mathrm{dBm}$ & $26 \mathrm{dBm}$ \\
Transfer rate & $400 \mathrm{Mbps}$ & $150 \mathrm{Mbps}$ \\
Power consumption (maximum) & $15 \mathrm{~W}$ & $8 \mathrm{~W}$ \\
\hline
\end{tabular}

Source: self-made.

Looking at both technologies, with the exception of maximum energy consumption, technical characteristics present similar values and meet technical requirements to link establishing. The difference between maximum power consumption values is due to the number of antenna connection ports. Ubiquiti PowerBeam radio transmitters (airMAX technology) have connection ports for one antenna only, while WiBACK nodes have the facility for two antenna connections, averaging a maximum of $7.5 \mathrm{~W}$ per link (splitting maximum consumption value). According to WiBACK technical data sheet, each node has an average consumption of $9 \mathrm{~W}$; on the other hand, Ubiquiti technical documentation specifies its maximum consumption on $8 \mathrm{~W}$ omitting the average consumption.

An additional challenge related to devices energy consumption for networks installation in rural areas is presented since electricity supply from commercial networks may not exist. Field technical visits revealed that two network points were in areas without traditional electricity supply: Almagra and La Peña. Photovoltaic systems were installed in Almagra and La Peña to power communications equipment and tower's security lights. The higher the electrical load that the photovoltaic system must maintain, the greater the technical requirements of its elements and, therefore, the investment cost.

On the other hand, both technologies have software to monitor and manage their devices, providing information such as the identification of each device, working frequency, signal levels, and length links calculation to the network administrator. In addition, both technologies can automatically change their working frequency based on the electromagnetic spectrum analysis [29].

\subsection{WiBACK Network Devices and Measurements}

WiBACK network monitoring software shows the implemented network topology and presents real-time data and characteristics of each link. In Figure 3 are shown established links between network nodes (Chalán-Almagra and Almagra-La Peña) with their respective signal levels measured in decibels $(\mathrm{dB})$.

According to WiBACK established parameters to measure devices' performance, signal levels between 30 and $70 \mathrm{~dB}$ are referred to suitable performance, and optimal signal levels are those in the range of 51 to $70 \mathrm{~dB}$ [16]. Obtained network evaluation values are at optimal signal levels: Chalán-Almagra link presents values of 55 and $57 \mathrm{~dB}$, and Almagra-La Peña link shows values of 51 and $52 \mathrm{~dB}$.

\subsection{UBIQUITI Network Devices and Measurements}

Ubiquiti radio transmitters software airOS ${ }^{\mathrm{TM}}$ consists of several menus for equipment configuration, wireless links status visualization, and hardware use, as shown in Figure 4. It also facilitates antennas alignment and electromagnetic spectrum scanning. 


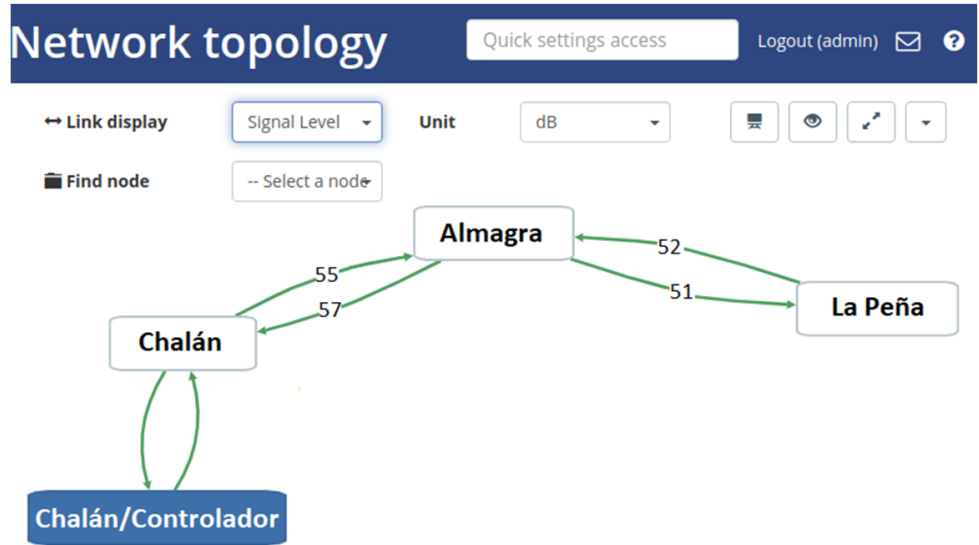

Figure 3. Signal levels between WiBACK network nodes. Source: WiBACK network monitoring software.

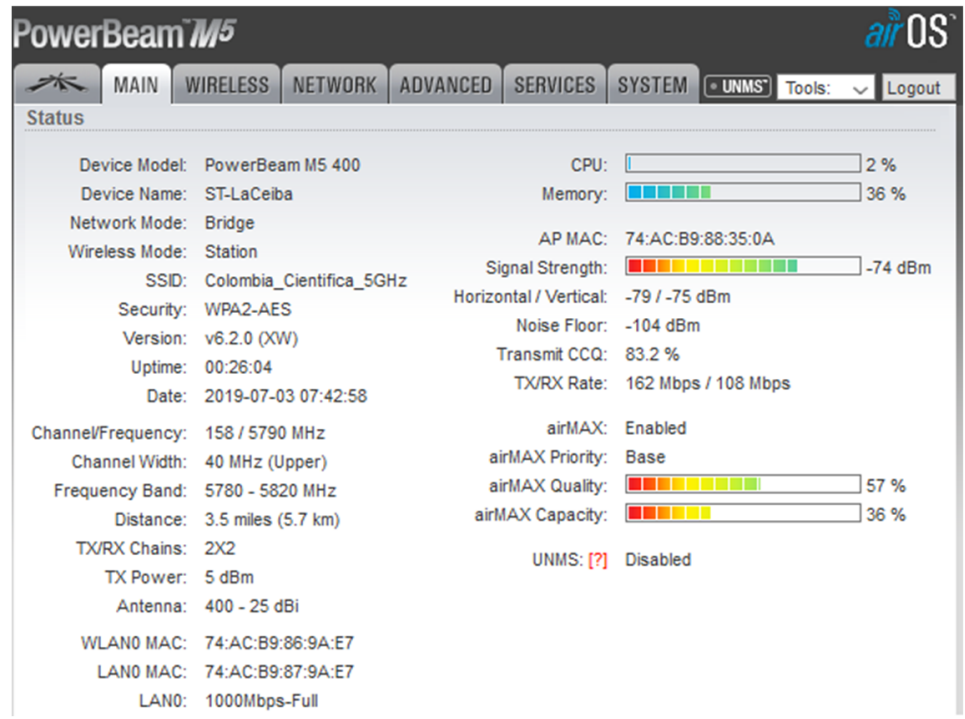

Figure 4. Ubiquiti link stats and data. Source: Ubiquiti radio transmitters software airOS ${ }^{\mathrm{TM}}$.

It can be seen in airOS ${ }^{\mathrm{TM}}$ software a summary of current device configuration and established links. Among the information presented in this summary, the device model and name assigned stand out. It can also be found information about the connected network, such as type of security protocol implemented, current transmission power, and working frequency and channel width. In airOS ${ }^{\mathrm{TM}}$ software, hardware use graphical representation in real time (CPU and memory) stands out. Signal strength between Almagra and La Ceiba nodes can be observed through a bar, measuring $-74 \mathrm{dBm}$ and presenting green color, which is interpreted as a suitable signal level since the maximum reachable value for this graph is $-64 \mathrm{dBm}$. Finally, bars corresponding to airMax quality to measure link quality (in percentage) and airMax capacity to measure transmission channel percentage use when multipoint links are created (several clients connected to the same device in star topology) are shown [30].

\section{Results of WiBACK Rural Backhaul Network Spectral Measurements in Ovejas and Chalán Municipalities, Sucre, Colombia}

Spectral map measurements allow first to settle the optimal working frequency between Almagra and La Ceiba nodes depending on available frequencies, and indirectly, the installed network nodes present differences in terms of population density depending on the location. The network node located on the Almagra hill stands out among installed network nodes because it is the only one that is not located within a populated center, 
contrary to installed nodes in Chalán municipal seat and La Ceiba and La Peña townships. Located in Ovejas rural area with a scattered population, repeater tower is installed in one of the highest points of Almagra hill (Figure 5); this low population density characteristic makes it possible to select Almagra node to compare electromagnetic spectrum occupation in a specific bandwidth. To perform this analysis, it is necessary to measure radio signals amount, working frequencies, and power of active devices around node location. This measurement is called spectral analysis, as an electromagnetic spectrum scan is performed. In this case study, electromagnetic spectrum measurements were performed between 5725 and $5825 \mathrm{MHz}$ from the network central point located in the repeater tower-Almagra hill; in this point, communication devices corresponding to Chalán, La Peña, and La Ceiba nodes are linked. Additionally, spectral measurements in the La Ceiba node were performed to compare the electromagnetic spectrum occupation between an area with a scattered population and an area with a higher population density. In Figure 5, delimited perimeters marked in yellow over the map are presented. The left-side figure shows La Ceiba (Chalán municipality township), a higher population density area concentrated in $10 \mathrm{~km}^{2}$, and the right-side figure shows Almagra hill (Ovejas municipality rural area) surrounding area with a scattered population.

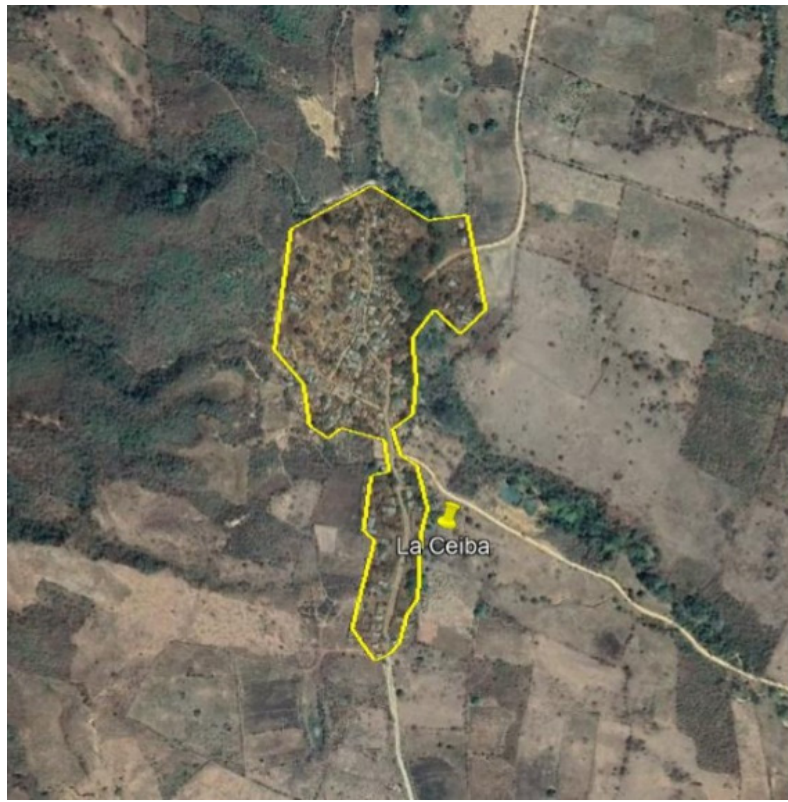

(a)

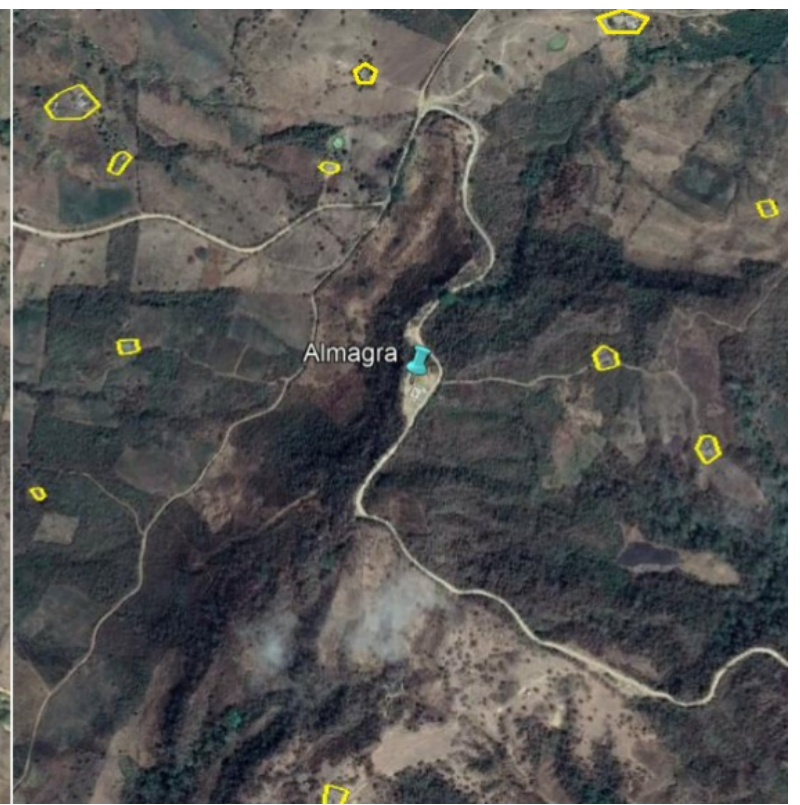

(b)

Figure 5. Delimited perimeters. La Ceiba municipality (a) and Almagra hill surrounding area (b). Source: Google Earth.

Spectral measurements in $5 \mathrm{GHz}$ frequency band and graphs generation are carried out using AirView Spectrum Analyzer software incorporated in Ubiquiti devices. The resulting spectral measurements of Almagra and La Ceiba nodes are analyzed. The spectral measurements are presented graphically in Figures 6 and 7; abscissa axis corresponds to evaluated frequencies, and the ordinate axis represents the scan elapsed time (in seconds).

Figures 6 and 7 show Almagra and La Ceiba nodes frequency analysis in waterfall view, where the color range in the upper right part of each figure represents power levels for each frequency in the selected range. In Almagra node measurements (Figure 6), the dark blue color represents the lowest level $(-117 \mathrm{dBm})$, passing through the intermediate levels in green and yellow colors before reaching the maximum level, represented in red color (-97 dBm). Similarly, La Ceiba node measurements show close values in the lowest signal intensity $(-117 \mathrm{dBm})$, but the highest signal intensity varies $(-82 \mathrm{dBm})$, as can be seen in Figure 7. 


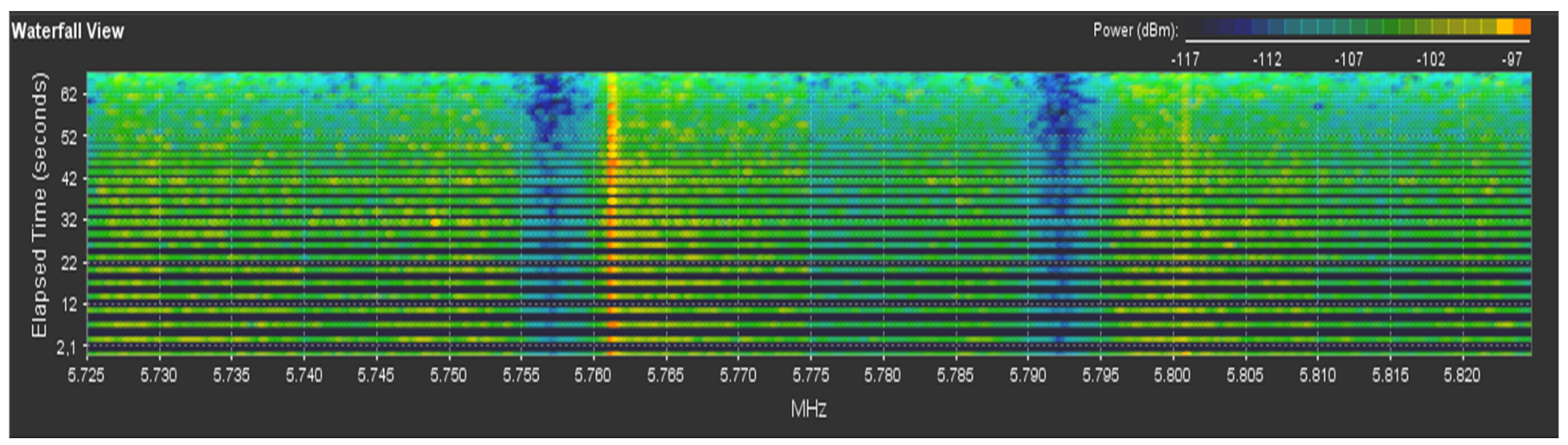

Figure 6. Waterfall view of Almagra node frequency analysis in Ovejas municipality rural area. Source: AirView Spectral Analyzer software.

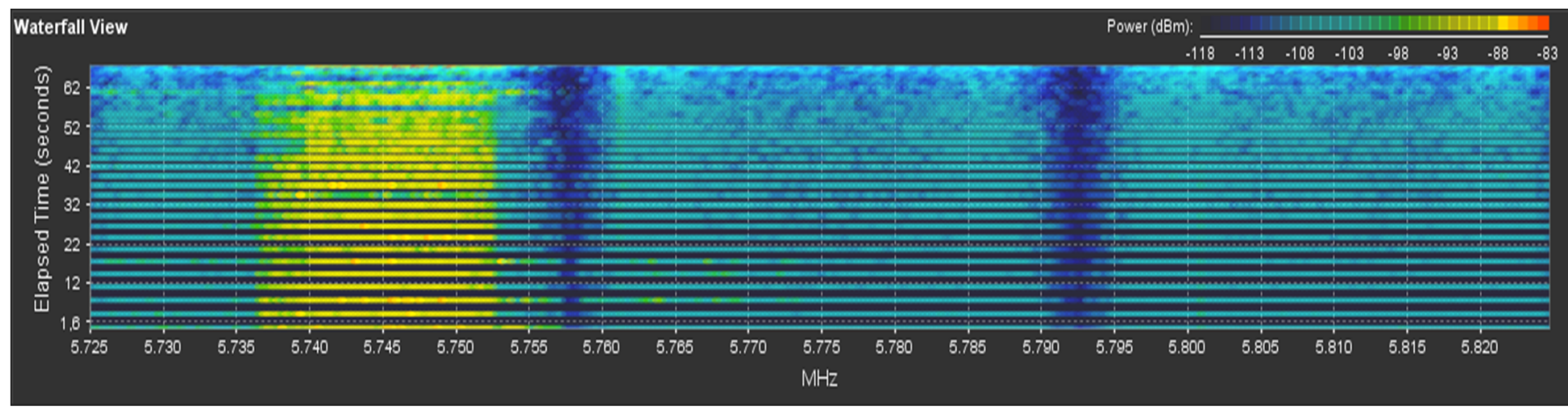

Figure 7. Waterfall view of La Ceiba node frequency analysis in La Ceiba township. Source: AirView Spectral Analyzer software.

Almagra and La Ceiba node measurements coincide in those frequencies where the lowest power levels were recorded (dark blue color between 5755 and $5760 \mathrm{MHz}$ and 5790-5795 MHz). However, they differ in the maximum power levels values recorded since in La Ceiba node measurements, and there are no red marks.

According to the color ranges presented in Figures 6 and 7, the Almagra node shows a radiofrequency signals incidence that covers most of the scanned frequencies at mediumhigh power levels. The Almagra hill, due to its elevation, represents an obstacle to the line of sight for point-to-point links between the municipalities of Ovejas and Chalán. At the same time, it is also used as a strategic site to install signal repeater towers in its highest parts, making Almagra hill is a place where the following trajectories of multiple signals interconnect the municipalities with each other and with their townships coincide.

Figures 8 and 9 show Almagra and La Ceiba nodes frequency analysis in waveform view; the abscissa axis corresponds to evaluated frequencies, and the ordinate axis represents the detected signals power levels (in $\mathrm{dBm}$ ).

Figures 8 and 9 record electromagnetic noise levels in the area by measuring its power in decibel milliwatts $(\mathrm{dBm})$. The color range represents the number of times a power value was recorded using each frequency between 5725 and $5825 \mathrm{MHz}$, where blue color represents zero samples and red color represents 100 detected samples. According to Almagra node measurements (Figure 8), red color marks were observed all along evaluated frequencies in power levels around $-110 \mathrm{dBm}$, and consistently, the frequency ranges that record fewer data were the same that presented the lowest power levels in Figure 6.

Unlike Almagra node measurements, in La Ceiba, node spectral noise analysis presented in Figure 9 were measured a $-87 \mathrm{dBm}$ power level between 5735 and 5755 . It was also observed that electromagnetic noise levels remain lower $-100 \mathrm{dBm}$ in the frequency range evaluated, and consistently, the frequency ranges that record fewer data were the 
same that presented the lowest power levels. Red color marks were observed all along evaluated frequencies in power levels around $-110 \mathrm{dBm}$ in Figure 9.

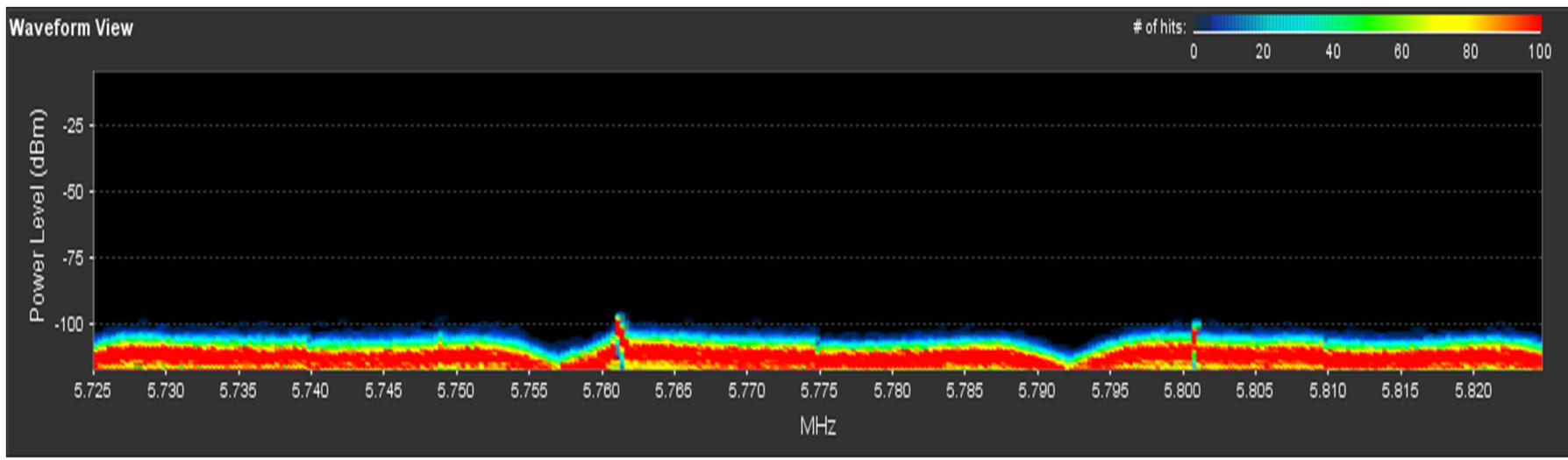

Figure 8. Waveform view of Almagra node frequency analysis in Ovejas municipality rural area. Source: AirView Spectral Analyzer software.

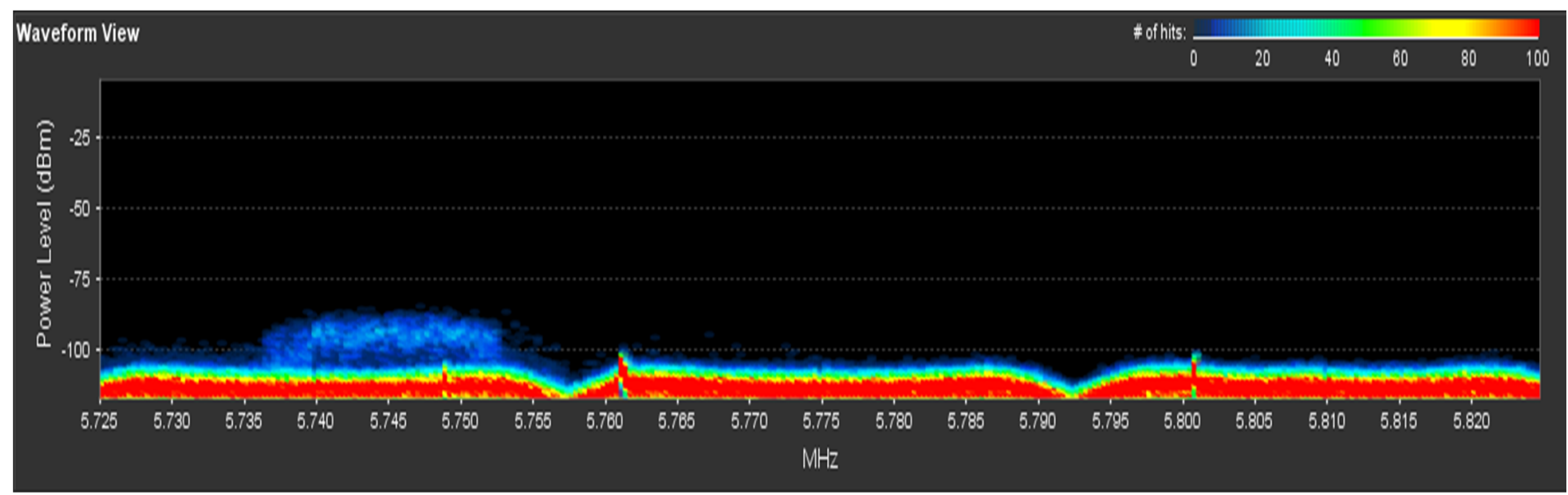

Figure 9. Waveform view of La Ceiba node frequency analysis in La Ceiba township. Source: AirView Spectral Analyzer software.

Additionally, looking at Figures 8 and 9, it could be seen a difference between power levels measured in the Almagra node (Ovejas municipality rural area) and La Ceiba node (Chalán municipality township). Red color indicates a greater number of wireless signal samples using the $5 \mathrm{GHz}$ frequency band, indicating that when telecommunication devices use increase, population density increase too.

\section{Conclusions}

In such a diverse geography as Colombia owns where connectivity for rural areas is a necessity, WiBACK technology is presented as a useful tool thanks to its technical characteristics, e.g., its ability to self-adjust the working frequency and its low energy consumption, which allows the photovoltaic solar energy use to power the communication devices. These technical characteristics added to Ovejas and Chalán municipalities identification as territories affected by Colombian intern armed conflict, making the backhaul network implementation an opportunity to shorten the digital divide. Unlicensed frequency bands in Colombia are an option for rural connectivity. The unlicensed $5 \mathrm{GHz}$ frequency band analysis was presented in Figures 6-9 between two network nodes. Spectral maps observation allowed to settle the working frequency at $5790 \mathrm{MHz}$ and, according to Almagra and La Ceiba nodes spectral analysis, from 5735 to $5755 \mathrm{MHz}$, the highest difference in power between both nodes is found. La Ceiba node presented the highest intensity with $-87 \mathrm{dBm}$, and the Almagra node presented with $-102 \mathrm{dBm}$. 
La Ceiba node is in an urban area; therefore, it has a higher population density, while the Almagra node is located in a rural elevated area with a scattered population; therefore, it has a lower population density. Power levels intensity measured in Almagra and La Ceiba nodes and presented in waveform views frequency analysis indicate that when population density increases, telecommunication devices use, and power levels increase too. This relationship will be explored in future research works where electromagnetic radiation from electronic devices would be continuously observed on the spectral map. A more detailed frequency spectrum analysis would make it possible to observe indirectly other demographic behaviors in those territories where conventional demographic measurement methods have coverage limitations, e.g., internal migration measurement needs continuous population records that are limited due to implementation and operation costs.

Author Contributions: Conceptualization, C.L.C., M.A.M.-A. and N.G.-G.; methodology, C.L.C., M.A.M.-A. and N.G.-G.; software, C.L.C., M.A.M.-A. and N.G.-G.; validation, C.L.C., M.A.M.-A. and N.G.-G.; writing—original draft preparation, C.L.C., M.A.M.-A. and N.G.-G.; writing-review and editing, C.L.C., M.A.M.-A. and N.G.-G. All authors have read and agreed to the published version of the manuscript.

Funding: This work was supported by Colombian Ministry of Science, Technology and Innovation for national doctorates (grant number 647, 2014), and Universidad Nacional de Colombia "Convocatoria para el Apoyo al Desarrollo de Tesis de Posgrado y Trabajo de Grado de pregrado de la Facultad de Ingeniería y Arquitectura de La Universidad Nacional de Colombia-sede Manizales 2020", Modality 1: Support for doctoral thesis in any area of knowledge, with research project "PHASE RESPONSE ESTIMATION BASED ON DEEP LEARNING TECHNIQUES FOR FREQUENCY SELECTIVE CHANNELS" (code Hermes 50916).

Institutional Review Board Statement: Not applicable.

Informed Consent Statement: Not applicable.

Acknowledgments: This work is associated with Colombia Científica program "Reconstrucción del Tejido Social en Zonas de Posconflicto en Colombia" and particularly to "Modelo Ecosistémico de Mejoramiento Rural y Construcción de Paz: Instalación de capacidades locales" project, financed by the Fondo Nacional de Financiamiento para la Ciencia, la Tecnología y la Innovación, Fondo Francisco José de Caldas contract number 213-2018 and code 58960.

Conflicts of Interest: The authors declare no conflict of interest. The funders had no role in the design of the study, in the collection, analyses, or interpretation of data, in the writing of the manuscript, or in the decision to publish the results.

\section{References}

1. Transformar Nuestro Mundo: La Agenda 2030 para el Desarrollo Sostenible. Available online: https://unctad.org/meetings/es/ SessionalDocuments /ares70d1_es.pdf (accessed on 6 October 2020).

2. ITU: Committed to Connecting the World. Available online: https://www.itu.int/en/ITU-D/Statistics/Pages/stat/default.aspx (accessed on 4 October 2020).

3. Connecting the Unconnected-Tackling the Challenge of Cost-Effective Broadband Internet in Rural Areas. Available online: https://www.wiback.org/content/dam/wiback/en/documents/Study_Connect\%20the\%20Unconnected_2019.pdf (accessed on 7 October 2020).

4. Santoyo, A.S.; Martínez, E.M. La Brecha Digital: Mitos y Realidades; Departamento Editorial Universitaria de la Universidad Autónoma de Baja California: Mexicali, México, 2003.

5. Plan de Acción para la Transformación Regional-PATR Subregión Montes de María. Available online: https://www. renovacionterritorio.gov.co / descargar.php?idFile=23339 (accessed on 15 October 2020).

6. Flax, J. Construcción institucional de confianza. Cuad. Ética 2006, 21, 35-59.

7. Niephaus, C.; Aliu, O.G.; Kretschmer, M.; Hadzic, S.; Ghinea, G. WiBACK: A Back-haul network architecture for 5G networks. In Proceedings of the International Conference on Frontiers of Communications, Networks and Applications (ICFCNA 2014Malaysia), Kuala Lumpur, Malaysia, 3-5 November 2014; pp. 1-6. [CrossRef]

8. CONPES 3918-Estrategia para la Implementación de los Objetivos de Desarrollo Sostenible (ODS) en Colombia; Departamento Nacional de Planeación: Bogotá, Colombia, 2018.

9. RedVolución. Available online: https:/ / colombiatic.mintic.gov.co/679/w3-propertyvalue-36669.html (accessed on 5 October 2020). 
10. Informe de Acciones de Política para el Cierre de la Brecha Digital. Available online: https://www.mintic.gov.co/portal/604/ articles-62254_Documento_de_Cierre.pdf (accessed on 5 October 2020).

11. Por la Cual se Modifica la Resolución 711 de 2016 para Establecer las Condiciones de uso de los Dispositivos de Espacios en Blanco- PDET; Resolución No 461 de 2017; Agencia Nacional del Espectro: Bogotá, Colombia, 2017.

12. Connecting the Unconnected with WiBACK. Available online: https:/ / www.wiback.org/ (accessed on 18 January 2022).

13. PTP 550/550e-5 GHz Unlicensed Band Solution featuring DCS \& AES. Available online: https://www.cambiumnetworks.com/ products/backhaul/ptp-550/ (accessed on 18 January 2022).

14. B5c Specifications. Available online: https://mimosa.co/products/specs/b5c (accessed on 18 January 2022).

15. NetMetal 5SHP Triple. Available online: https://mikrotik.com/product/RB921UAGS-5SHPacT-NM (accessed on 18 January 2022).

16. WiBACK Rel. 4.3. User-Guide. Available online: https://www.wiback.org/ (accessed on 15 January 2021).

17. Arrieta, V.V. Caracterización del Proceso Asociativo en los Montes de María. Caso: Departamento de Sucre. Master's Thesis, Departamento de Economía, Universidad Tecnológica de Bolívar, Cartagena de Indias, Colombia, 2017.

18. Aguilera, M. Montes de María: La economía en los Montes de María. Rev. Econ. Región. 2014, 8, $91-141$.

19. Cortés, C.L.; Montaño-Argote, M.A.; Osorio, A.M.; Guerrero-González, N. Diseño de una red backhaul autogestionable para conectividad rural en Sucre-Colombia. Rev. UIS Ing. 2021, 20, 67-78. [CrossRef]

20. TerriData. Objetivos de Desarrollo Sostenible-Penetración Banda Ancha. Available online: https://terridata.dnp.gov.co/indexapp.html\#/comparaciones (accessed on 5 May 2020).

21. Índice ODS 2019 para América Latina y el Caribe. Available online: https:// cods.uniandes.edu.co/wp-content/uploads/2020/0 6/\%C3\%8Dndice-ODS-2019-para-Am\%C3\%A9rica-Latina-y-el-Caribe-2.pdf (accessed on 7 May 2020).

22. Salaya, H.E.; Rodriguez, J. La dinámica poblacional y la violencia armada en Colombia, 1985-2010. Rev. Panam. Salud Publica 2014, 36, 158-163. [PubMed]

23. Valencia Agudelo, G.D. El posconflicto colombiano es centralista y no territorial como se prometió. Rev. Estud. Polit. 2018, 53, 9-15. [CrossRef]

24. Serie Población, Ordenamiento y Desarrollo, Guía No. 1 Elementos Poblacionales Básicos para la Planeación, Segunda Edición. Available online: https:/ / colaboracion.dnp.gov.co/CDT/Desarrollo\%20Territorial/ELEMENTOS\%20POBLACIONALES\%20 -\%20MVCT.pdf (accessed on 20 April 2021).

25. Registro Único de Víctimas—Unidad de víctimas. Available online: https:/ / www.unidadvictimas.gov.co/es/registro-unico-devictimas-ruv/37394 (accessed on 2 February 2022).

26. Proyecciones Nacionales y Departamentales de Población 2005-2020. Available online: https://www.dane.gov.co/files/ investigaciones/poblacion/proyepobla06_20/7Proyecciones_poblacion.pdf (accessed on 7 January 2020).

27. Por el cual se crean los Programas de Desarrollo con Enfoque Territorial_PDET; Decreto 893 de 2017; Ministerio de Agricultura y Desarrollo Rural: Bogotá, Colombia, 2017.

28. Connecting Everything Everywhere. Available online: https:/ / careers.ui.com/ (accessed on 27 January 2021).

29. The Electromagnetic Spectrum: A Critical Natural Resource. Available online: https://digitalrepository.unm.edu/nrj/vol25/iss3 / 6 (accessed on 15 January 2021).

30. AirOS 6 User Guide. Available online: https:/ / dl.ubnt.com/guides/airOS/airOS_6_UG.pdf (accessed on 31 January 2021). 